\title{
The Lack of Recognition of the Rights of Children in Street Situations. An Approach from the Theoretical Proposal of Axel Honneth
}

\author{
Dra. Yasmín Hernández Romero \\ M. en D.I. Yissel Hernández Romero \\ Lic. Erika Jazmín Amador Lugo \\ Centro Universitario UAEM Zumpango \\ Universidad Autónoma del Estado de México \\ México
}

\begin{abstract}
In this essay the theory of the recognition of Axel Honneth is taken up, in which three fundamental spheres are established for the integration of the people in society: affective, legal and social. The use of this theory explains the lack of recognition of street children and the violation of their rights. The progress made in the legal sphere in Mexico is deepened. Despite the progress in the regulations and the actions undertaken, Honneth's approach warns of dimensions that should be considered by public decision-makers and by civil society.
\end{abstract}

Keywords: Children's rights, Street children, Social integration, Social justice, Public politics. (Unesco-OIE Educational Thesaurus).

\section{Introduction}

The issue of children becomes important nationally and internationally since the twentieth century, objectifying in a legal framework and public policies for their attention. International organizations, such as the United Nations Children's Fund (UNICEF), the United Nations Educational, Scientific and Cultural Organization (UNESCO) and the World Health Organization (WHO), have influenced the governments of different countries to adopt policies in favor of this population group. That is the reason why the twentieth century is known as the "century of children".

This document explores the attention that has been given to a sector of greater social vulnerability: children in street situations. Although, in the field of public policy, various aid programs have been undertaken aimed at development in poor countries and at the attention of vulnerable population, the results are not entirely satisfactory; due to the lack of follow-up on the actions and programs undertaken.

In the academy, the issue of street children has been the subject of various investigations, with approaches from medicine, psychology, law, social work, pedagogy, history, anthropology and sociology. Even when the highest academic production has been located since the eighties of the twentieth century, has been present tangentially in some works of the mid-nineteenth century. The literature has shown that this problem is correlated with: poverty, migration, violence, family disintegration, addictions, war, to name a few variables.

In this essay, the theory of the recognition of Axel Honneth is used to explain the violation of the rights of children in street situations. This theory establishes three fundamental areas for the achievement of social recognition, applicable to all social groups, which allow the problem to be approached in several dimensions, which must be considered by public decision-makers and by civil society. The document is organized in five sections. In the first, historical information about the presence of street children and social consideration towards them is recovered. In the second, different concepts used to name these children are presented, analyzing their implications. In the third one, Honneth's theoretical proposal about recognition is established, presenting the three fundamental types of recognition for the integration of individuals into society. In the fourth, the theoretical approach of Honneth is used to account for the violation of the rights of children in street situations. In the fifth, we reflect on the normative recognition of street children in Mexico. It ends with some conclusions on the subject. 


\section{Street children in history}

A historical testimony about the existence of street children is mentioned in the Encyclopedic Historical Dictionary (1830), which refers to the actions established by the Roman emperor Trajan, ruler of the year 98 to 117, who created a hospice where the poor children were taken; probably this was one of the first places of assistance.

Another reference is in the sixteenth century, with the issuance in England of the first Law of the Poor, in the year 1601, whose intention was to suppress the wandering through the institutionalization of a system of charity. At that time, social assistance was in the hands of the church. In 1834 the so-called New Poor Law was established, which replaced the aid to those in need by the creation of a system of workhouses, as well as a national central body for its administration. (Rodríguez Caballero, 2003).

Herbert Spencer (1884) made a critique of the New Law of the Poor, in his work The individual against the state. Spencer defends the criterion of "laissez faire" against the intervention of the State in the life of individuals, which, he argued, favored the existence of a permanent body of vagabonds. From this perspective, it can be observed that poverty was conceived as a result of the inability of the individual to satisfy his needs, since he is the only one responsible for his destiny.

On the other hand, Cunningham (1999) indicates that it was not until the middle of the 19th century that people began to reflect on the rights of poor children. Within the population of poor children, there are some that are doubly invisible: children in a street situation. It should be noted that the glances towards these children oscillate between feelings of charity, contempt and even fear.

From then on, it begins the configuration of a modern system of interventions and regulatory controls around children in street situations. "These children were initially seen as a danger, as "savages" who could subvert the stability of mid-Victorian civilization. But they also caused pity, were seen as "abandoned and lost" or "scoundrels" in need of being rescued so they could live their childhood; at the same time, possessing beauty, fragility and freedom in the face of social conventions that made them a picturesque drawing of the urban scene." (Cunningham, 1999: 3).

In Mexico, the first references of children in street situations go back to the time of the Colony. The ambivalent attitude toward them is expressed, on the one hand, in the establishment of the Houses of Charity and, on the other, of the Courts of Vagos in the district and territories of the early nineteenth century. In this regard, the House of Charity and Mercy, inaugurated in Guadalajara in 1810, served at an institution for teaching, charity, correction and beneficence; whose foundation is found in the Christian moral obligation of help and mercy; whose foundation is based in the Christian moral obligation of help and mercy; In this House children of both sexes whose parents could not afford their support, sick, orphans and homeless, as well as women and children of married men, would be admitted. (Gutiérrez Lorenzo, 2007). On the other hand, the lazy were persecuted and arrested; in the Decree of February 3, 1845 it was established that those minors who were designated as lazy, would receive the teaching of a trade in any of the workshops that would like to receive them "taking care that they do not escape." (Pérez Toledo, 1993: 33).

With respect to punitive institutions, Reyes and González (2010) present a historical review of the institutions established in Mexico for the regulation and control of juvenile offenders; in this text are reported the problems that the minors have faced, from the first Courts of vague ones in the district and territories, happening through the courts of the children of the street and in the street, the correctional or reform school, until the internment centers, whose education programs remain stagnant, and where violence is a constant, reproducing the socialization of criminal behavior.

In that order of ideas, children living on the street "are often singled out, not so much as subjects in danger, but as dangerous, as victims who become perpetrators and in front of whom, rather than thinking about protection and permanent care, there is constant observation and intensive control."(Marín Díaz, 2011: 68).

In summary, it can be said that throughout history different forms of social interaction have been established with children in street situations, which underlie some of these two logics.

\section{Children in street situations: a concept under construction}

Considering that the categories from which individuals are "named", and classified as part of a social group, respond to specific socio-historical conditions, which implies a series of relational aspects with other groups. 
Thus, over time you can find different categories, such as: homeless children, homeless, homeless or street children. Whose features in common are: to be in conditions of poverty and insecurity, along with the minority.

However, as it is a complex, dynamic and, in some cases transitory, situation, it has led to the establishment of conceptual distinctions. One of them was established in the First Latin American Seminar on Community Alternatives for Street Children (UNICEF, 1984), which differentiates between:

- Street children - those who have broken family ties and spend the night on the street.

- Children on the street. - Those who carry out income generating activities in different spaces, such as public roads, however, these children live with their families.

- Children at risk of living on the street. - They live in conditions of poverty, which puts them in a situation of vulnerability and could get to settle down in the street.

The difference between children and street children is widely used; however, Koller and Hutz (1996, cited in Nieto and Koller, 2015), argue that this distinction -whose basis is the contact with the family, and the existence of a home to which they return at some time of the day-, may not be appropriate because there are other possible combinations. In this sense, for these authors it is more appropriate to call them "street children". In this argumentative line, Nieto and Koller (2015), provide elements for such categorization:“... the terms "street children" or "children on the street" suggest that they do not belong to a family, that they do not have a social context that includes them, and therefore can become a preconception, being more appropriate to name them "In a street situation", as suggested by Koller and Hutz (1996).” (page 2172)

In this document we take up the concept of street children, which allows us to account for the conditions of social vulnerability in which they find themselves, not only in the family environment, but also in a broader social context.

In Mexico, for example, the concept of an indigenous street child is also discussed. The above complicates the analysis, since indigenous children usually belong to complete families living on the street; In addition, one of the main variables to consider a child under the concept of a street child is precisely the breaking of the family bond. Likewise, the social dynamic has modified the profile of children who are in a street situation. Actually, the presence of girls is increasing, which has led to the formation of street families in the face of an active sexual life. The importance of establishing the diversity of situations goes beyond the conceptual rigor for academic purposes, since in the establishment of public policies and government programs the definition of the target population constitutes the starting point for their attention. Bearing in mind that the existence of children in street situations does not derive solely from the problems that arise in the family nucleus, but is part of a wider social configuration, the actions for their prevention and control will have to be of that wingspan.The theory of the recognition of Axel Honneth allows to explain the condition of street children from a social perspective of vulnerability and social exclusion; reason why it will be retaken in the next analysis.

\section{The recognition theory of Axel Honneth}

For Axel Honneth, a member of the third generation of the Frankfurt School, recognition is understood as the fundamental element of the constitution of human subjectivity. (Tello Navarro, 2011). For Honneth, "the human being is only constituted as such in relation to other human beings in an intersubjective medium of interaction." (Tello Navarra, 2011: 46).

Honneth recovers the Hegelian idea about identity as intersubjective construction and the recognition of others as a condition for recognition itself. The foregoing implies that "the reproduction of social life is fulfilled under the imperative of reciprocal recognition". (Honneth, 2009: 254). In the same sense, the notion of recognition "is not only a courtesy that we owe to others: it is a vital human need." (Taylor, 2009: 42).

For Honneth there are three types of recognition, which are fundamental for the integration of individuals into society. Each of the types of social recognition is related to a sphere, whose base is the tripartite separation between family, State and society.“... I have distinguished, as I mentioned, between three forms of social recognition that can be considered communicative conditions of a proper identity formation: emotional affection in intimate social relationships, such as love and friendship, legal recognition as a member of a society who is morally responsible for their actions and, finally, the social valuation of individual performance and capabilities." (Honneth, 2009: 267) 
The first of these forms occurs in the affective relationships of childhood from the family bond: in the so-called sphere of love, understood in a broad sense of care and attention. The second is expressed in the legal regulations and their application. The third refers to the public recognition of value as a person.

Recognition is a condition for life in society; its lack brings with it many severe consequences for the person. The lack of recognition in any of the spheres corresponds to a type of damage:"... mistreatment, rape, torture and death in the sphere of love; dispossession of rights, fraud and discrimination in the right; and injury and stigmatization in the sphere of social solidarity. These damages break some form of self-relation of the individual with himself: self-confidence in the first of the spheres, self-respect in the second and self-esteem in the last." (Tello, 2011: 47) In the sphere of love, the damage will occur on the individual level, at first. In the other two spheres the damage is linked to the social value of the person or group, in terms of the dominant legal and cultural framework, and social contempt. (Tello, 2011).

From this perspective, Honneth explains the social conflict and, above all, the source of motivation of the struggles and moral conflicts throughout history. The moral struggle of recognition has brought with it the generation of social movements (feminists, homosexuals, indigenists, displaced, etc.), which open gaps towards the incorporation, participation and integration of the excluded into society at a given social historical moment.

Thus, struggles for recognition have led to a moral development of society. It is an unfinished process since at present there are still several groups that lack recognition in any of the areas mentioned. A process that for Honneth is not linear nor free of contradictions.

\section{The lack of recognition towards children in street situations}

In this section we make use of Honneth's proposal to delve into the understanding of a social group in which injustice and social contempt are visible in an extreme way: children in a street situation.

\subsection{Sphere of love}

The family is the primary institution, linked by ties of kinship, responsible for providing the child with the basic care and satisfaction to meet their human needs during this stage. This institution maintains its own internal logic, but it is also located in a wider socioeconomic configuration that influences the fact that the child does or does not meet his needs. Under these circumstances, in some cases children are pressured to leave the relationship of family dependence, and perform some activity to satisfy the shortcomings, either their family or their own. Facing adverse conditions and the risks presented by the street.

According to Cornejo (1999), in addition to the conditions of poverty that prevail in the homes of "street children", family interactions are marked by aggression and violence, a situation that is replicated from generation to generation by the own social dynamic in which they live. Given this scenario, the street will become, for the child, a space of survival and belonging, from whose interactions with other actors (other children in the same situation, population in general, police and institutions responsible for the control and regulation of populations street) will generate an identity.

From a socio-clinical perspective, Taracena (2012) points out that there are cases of "expelling families" of children to the street, intervening social and individual factors. In some cases, they are migrant families living in precarious conditions. However, there is no direct relationship between the poverty factor and the street situation, while there have been cases of children coming from other social sectors. Taracena alludes that not all difficult experiences in the family end up on the street, contrary to the dominant beliefs, making sense of the "singularity of personal history" (2012: 37). For this author, the absence of a parental project, will affect the conformation of the identity of the child.

Based on the above, the influence of individual dimensions, family members and the environment itself or community is visualized in the dynamics of the so-called sphere of love.

\subsection{Legal sphere}

The regulations established around children in street situations express the feelings of a community in a given time and space, since the right is social. (Durkheim, 2016). This, without leaving aside that the content of the laws also implies interests, protagonisms and agreements. At the international level, the Declaration of the Rights of the Child or Declaration of Geneva, approved in 1924, is the first instrument referring to the human rights of children, it establishes the obligations of adults towards infants; emphasizing, in his second article, the need for protection of any abandoned or orphaned child. 
Later, the Universal Declaration of Human Rights (1948) states that "motherhood and childhood have the right to special care and assistance. All children, born of matrimony or out of wedlock, have the right to equal social protection."(United Nations, 1948: Article 25, point 2). This Declaration gave guidelines for a series of amendments and the publication of the second Declaration of the Rights of the Child, in 1959. It will be up to this moment that children cease to be considered as an object of obligation, to be recognized as a subject of law. However, as it is a Declaration, its compliance was not mandatory.

Subsequently, the approval of the Convention on the Rights of Children was achieved by the General Assembly of the United Nations (1989), as binding on the States Parties, constituting, from that moment, the main guiding instrument of the rights of children; based on four principles: non-discrimination; the child's superior interest; the right to life, survival and development; and of participation and to be listened to. The Convention will be the basis for the establishment and harmonization of national regulations.

\subsection{Sphere of social valuation}

This sphere refers to the social valuation of the individual. For Honneth, a form of valuation is obtained from the contribution that is made to society through work; an activity that acquires centrality in modern society, because, based on work, the individual builds its security, and at the macro level it favors social cohesion. "The expression "to have a job" means for the employees the possibility of developing in a productive activity and, at the same time, ensuring the guarantees against the future. We can then define the ideal type of professional integration as the double security of material and symbolic recognition of work and social protection that derives from employment." (Paugam, 2012: 8).

In the case of street children, public recognition of value as a person is denied in several ways. At the international level, the Convention states that, "States Parties recognize the right of the child to be protected against economic exploitation and against the performance of any work that may be dangerous or hinder their education, or that is harmful to their health or to their physical, mental, spiritual, moral or social development."(United Nations, 1989: Article 32, point 1).

Likewise, Convention 138, established by the International Labor Organization (ILO), on the minimum age for admission to employment, specifies that "the minimum age established in compliance with the provisions of paragraph 1 of this article shall not be less than the age at which the school obligation ceases, or in any case, at fifteen years."(ILO, 1973: Article 2, point 3). However, in another article, of the same Convention, it indicates "the minimum age for admission to all types of employment or work that, due to its nature or the conditions in which it is carried out, may be dangerous for the health, safety or morals of minors. It must not be less than eighteen years"(ILO, 1973: Article 3, point 1). The above implies that by belonging to an age group is excluded from the right to work.

Despite this regulation, child labor is a reality. In this regard, ILO Convention 182, on the worst forms of child labor, obliges countries that ratify it, to adopt measures for the prohibition and elimination of the following forms:

(a) all forms of slavery or practices similar to slavery, such as the sale and trafficking of children, debt bondage and serfdom, and forced or compulsory labor, including the forced or compulsory recruitment of children to be used in armed conflicts;

(b) the use, recruitment or offering of children for prostitution, the production of pornography or pornographic performances;

(c) the use, recruitment or offering of children for the conduct of illicit activities, in particular the production and trafficking of narcotic drugs, as defined in the relevant international treaties, and

(d) work that, by its nature or by the conditions under which it is carried out, is likely to harm the health, safety or morals of children. (ILO, 1999: Article 3)

In this case, street children carry out little or no valued activities, whether legal or unlawful. Within these you can distinguish between:

"1) street workers, who bring together those who work in the street, although they still attend the school with some frequency, do not commit crimes and return home at night;

2) independent street workers who, unlike the previous ones, have begun to break family ties, attend school less frequently and exhibit some criminal behavior;

3) family members in street situations, who work and live with their family on the street, and; 
4) who live on the street and have broken contact with their families." (Lusk, 1992 cited in Nieto and Koller, 2015: 2174).

Unfortunately, in Mexico and the world there is no clear picture of child labor.

\section{The legal recognition of street children in Mexico}

In Mexico, the Convention on the Rights of Children was ratified on September 21, 1990. The federal and state legal framework has followed an updating process, whose reference is still the Convention. In this regard, in the year 2000, during the mandate of Ernesto Zedillo, article 4 of the Mexican Political Constitution was amended, adding the following paragraph:"Children have the right to satisfy their needs for food, health, education and healthy recreation for their integral development. The ascendants, guardians and custodians have a duty to preserve these rights. The State will provide what is necessary to promote respect for the dignity of children and the full exercise of their rights. The State will grant facilities to individuals so that they can contribute to the fulfillment of the rights of children." (DOF, 04/07/2000).

This section is relevant in the sense of establishing the right of children to care, as well as the obligation of guardians to safeguard that right, and the role of the State as a coadjutant in procuring it.

In 2011, during the government of Felipe Calderón, the sixth and seventh paragraphs of article 4 were reformed, incorporating the principle of the best interests of the child as the axis; which should prevail over the interest of other subjects. Being as follows:"In all decisions and actions of the State, the principle of the best interests of children will be observed and complied with, fully guaranteeing their rights. Children have the right to satisfy their needs for food, health, education and healthy recreation for their integral development. This principle should guide the design, execution, monitoring and evaluation of public policies aimed at children. The ascendants, guardians and custodians have the obligation to preserve and demand compliance with these rights and principles." (DOF, 12/10/2011).

In 2014, in the government of Enrique Peña Nieto, another paragraph was added to the article in question: "Everyone has the right to identity and to be registered immediately upon birth. The State will guarantee the fulfillment of these rights. The competent authority shall issue the first certified copy of the birth registration certificate free of charge."(DOF, 06/17/2014).

It should be noted that the right to identity is a fundamental right from which legal identity is granted to the person, which is a condition of other human rights such as: education, health, support programs, repatriation, special procedural rights, be protected against human trafficking (Jiménez, 2017). However, children in street situations, in many cases, fail to enforce this right, being an obstacle to their inclusion in most social programs, which are directed, as a priority, to children who are at risk of living on the street. Some of these programs, for example, seek to reincorporate children into the classrooms, so that they leave the street, through the granting of a scholarship.

In another order of ideas, in 2014 the article 123 of the Political Constitution of the United Mexican States was reformed, in this reform the minimum age for admission to employment was raised, indicating in Section A, section III: "It is prohibited to use of the work of children under fifteen. Those over this age and under sixteen will have a maximum of six hours."(DOF, 06/17/2014), which was in harmony with the provisions of the Convention. Another relevant aspect, in this same period of government, was the entry into force of the General Law on the Rights of Girls, Boys and Adolescents, published on December 4, 2014. Likewise, within the administration of the federal government (2012 -2018) was approved the National Program for the Protection of Children and Adolescents 2016-2018 (PRONAPINNA), which establishes strategies and lines of action in the area of rights and protection of children, with "special attention to the guarantee of the rights of children and adolescents who are in a particular situation of vulnerability."(Federal Government, 2017: 66).

However, the operating rules to which most social programs are subject, for example,Prospera Social Inclusion Program, considers, as a target population, households whose socioeconomic conditions prevent them from developing the capacities of their members in relation to food, health and education In spite of the advances in normative matters, the reality of children in street situations continues to show a failed recognition, due to the denial of their fundamental rights. In this regard, the Committee on the Rights of the Child of the UN, in the Concluding Observations on the consolidated fourth and fifth periodic reports of Mexico, expressed various concerns (2015), highlights, among others, the need for the effective implementation of the General Law on the 
Rights of Girls, Boys and Adolescents (LGDNNA) in the three levels of government; the harmonization between the different laws with the Convention and the LGDNNA; insufficient budget allocated to children; the prevalence of discrimination; torture or cruel or degrading punishment of children; sexual exploitation and abuse; child labor at risk; as well as the accessibility of teaching to street children. The regulation of child labor is announced as a priority issue in the public agenda due to the consequences it has on school dropout and the risks involved for the child worker. In this regard, the Ministry of Labor and Social Security issued, in 2016, the Charter of Human and Labor Rights for adolescents of working age.

\section{Conclusions}

Throughout this document we have reflected on children in street situations, and how the theory of Recognition proposed by Axel Honneth can help their understanding. For Honneth, the achievement of recognition occurs in three spheres: affective, legal and social, this being a necessary condition for social integration. However, in the analysis presented, it is evident that street children are vulnerable in all three spheres.

It has been commented previously that the causes that affect the situation of children in street situations are multiple. Therefore, the actions for their attention cannot be given from a partial or reductionist perspective. One of the contributions of the recognition theory of Honneth in the understanding of street children is that it makes visible other dimensions of subordination -additional to economic subordination-, such as: contempt, lack of social appreciation and legal recognition.

The implementation of relevant actions, articulated with other programs, is a task that corresponds to both the State and civil society, which will have to consider both dimensions of social injustice. Despite the actions undertaken in Mexico, the lack of social recognition of street children shows the great structural contradictions of the country. In which, in addition, the activities of daily survival of street children constitute their own denial as human beings, by placing them day by day in the face of social contempt and humiliation.

\section{References}

Cornejo Portugal, I. (1999). Los Hijos del Asfalto. Una Prospección Cualitativa a los Niños de la Calle. Convergencia. Revista de Ciencias Sociales, vol. 6, núm. 19, mayo-agosto, Toluca, UAEM, pp. 207-243.

Cunningham, H. (1999). Los hijos de los pobres. La imagen de la infancia desde el siglo XVII. El derecho a tener derecho. Infancia, Derecho y Políticas Sociales en América Latina. Volumen 2. Santafé de Bogotá: Unicef, pp. 251-266.

Diario Oficial de la Federación (2000). Reforma al artículo $4^{\circ}$ Constitucional. Publicada el 7 de abril de 2000.

Diario Oficial de la Federación (2011). Reforma al artículo $4^{\circ}$ Constitucional. Publicada el 12 de octubre de 2011.

Diario Oficial de la Federación (2014). Reforma al artículo $4^{\circ}$ Constitucional. Publicada el 17 de junio de 2014.

Diario Oficial de la Federación (2014). Reforma al artículo $123^{\circ}$ Constitucional. Publicada el 17 de junio de 2014.

Diccionario Histórico Enciclopédico (1830), Tomo III. Barcelona, Imp. Roca.

Durkheim, E. (2016). La división del trabajo social. Madrid,Ediciones Akal.

Gobierno Federal. (2017). Programa Nacional de Protección de Niñas, Niños y Adolescentes (PRONAPINNA), publicado en el Diario Oficial de la Federación (DOF), el 16 de agosto de 2017, México.

Gutiérrez Lorenzo, M. P. (2007). Archivo Hospicio Cabañas: investigación y rescate de una institución educativa en México. Siglo XIX. EducaçãoUnisinos, vol. 11, núm. 2, Brasil, Universidade do Vale do Rio dos Sinos, pp. 91-102.

Honneth, A. (2009). Crítica del agravio moral, patologías de la sociedad. México, Fondo de Cultura EconómicaUAM.

Jiménez García, H. A. (2017). El derecho a la identidad como base para el ejercicio de los derechos humanos de niñas, niños y adolescentes en situación de calle de la Ciudad de México. En J. A. López Velarde Campa (coord.), Los invisibles: niñas, niños y adolescentes en situación de calle en la Ciudad de México (pp. 117-143), Universidad Autónoma de Aguascalientes/ CDHDF/ Asamblea Legislativa, D.F.

Marín Díaz, D. L. (2011). Notas para pensar la constitución de un campo discursivo. En F. Cousiño Donoso y A. M. Foxley Rioseco (Ed.), Políticas Públicas para la Infancia (pp. 57-76). Santiago de Chile, Comisión Nacional Chilena de Cooperación con UNESCO.

Naciones Unidas (1948), Declaración Universal de Derechos Humanos, 10 de diciembre de 1948. 
Naciones Unidas (1989), Convención sobre los derechos del niño Resolución 44/25, aprobada el 20 de noviembre de 1989.

Naciones Unidas. Comité de los Derechos del Niño de la Organización de las NacionesUnidas(2015), Observaciones finales sobre los informes periódicos cuarto y quinto consolidados de México.

Nieto, C. J. y Koller, S. H. (2015). Definiciones de Habitante de Calle y de Niño, Niña y Adolescente en Situación de Calle: Diferencias y Yuxtaposiciones. Acta de Investigación Psicológica, Vol. 5, núm. 3, México, Universidad Nacional Autónoma de México, Facultad de Psicología, pp. 2162-2181.

OIT (Organización Internacional del Trabajo). (1973). Conveniosobre la edad mínima de admisión al empleo (C138), Ginebra.

OIT (Organización Internacional del Trabajo). (1999).Convenio sobre las peores formas de trabajo infantil (C182), Ginebra.

Paugam, S. (2012). Protección y reconocimiento. Por una sociología de los vínculos sociales. Papeles del CEIC, año 12, núm. 2, septiembre, España, Universidad del país Vasco, Centro de Estudios sobre la Identidad Colectiva, pp. 1-19.

Pérez Toledo, S. (1993). Los vagos de la ciudad de México y el Tribunal de Vagos en la primera mitad del siglo XIX. Secuencia, Revista de Historia y Ciencias Sociales, núm. 27, México, Instituto Mora, pp. 27-42.

Reyes, L. A., y González, J. de D. (2010). La genealogía de los niños de la calle y su educación en los Centros de Internamiento en México. Revista Latinoamericana de Ciencias Sociales, Niñez y Juventud, vol. 8, núm. 2, julio-diciembre, Manizales, Colombia, Centro de Estudios Avanzados en Niñez y Juventud, pp. 10391050 .

Rodríguez Caballero, J. C. (2003). La economía laboral en el período clásico de la historia del pensamiento económico (Tesis doctoral). Universidad de Valladolid, Facultad de Ciencias Económicas y Empresariales, Valladolid.

Spencer, H. (1884). El individuo contra el estado. Versión española de A. Gómez Pinilla, Valencia, F. Sempere y Ca. Editores.

Taracena Ruíz, E. (2012). Las familias expulsoras de niños y niñas hacia la calle. Género y salud en cifras. Revista oficial del Centro Nacional de Equidad de Género y Salud Reproductiva, enero-abril, volumen 10, núm. 1, México, Centro Nacional de Equidad de Géneroy Salud Reproductiva/Secretaría de Salud, pp. $31-40$.

Taylor, C. (2009), El multiculturalismo y "la política del reconocimiento". México, Fondo de Cultura Económica.

Tello Navarro, F. H. (2011). La esfera del reconocimiento en la teoría de Axel Honneth. Revista de Sociología, año 22, núm. 26, Santiago, Chile, Departamento de sociología, Facultad de ciencias sociales, Universidad de Chile, pp. 45-57.

UNICEF. (1984). Primer Seminario Latinoamericano sobre Alternativas Comunitarias para Niños de la Calle. Brasil. 